\title{
form
}

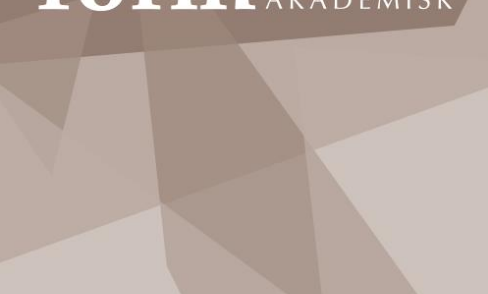

Vol I4, No 2 (2O2I)

\section{Patterned Silk Weaving in Ancient Times}

\section{A Study of Some Silks from Central-Asia Found in the Viking Area}

\begin{abstract}
Patterned silks came to Scandinavia as small pieces, valuable for the Vikings to have been used as trimmings on their garments. In over a millennium, the weave structure of samitum in these fragments was used in all patterned silk. In the Medieval times it was displaced by other structures. It has lapsed into obscurity for weavers today. For several reasons the study of these silks has been difficult. The fragments are fragile. They were not made in Norway. Few have mastered this weaving technique. Is it possible to reconstruct these ancient silks, based on the knowledge gained from studying historical silks and experience acquired from using the structure in modern textiles? This article is about my attempt to do so, and also my reflections on the possible longtime impact these silks had on the weaving tradition in Norway.
\end{abstract}

Keywords:

Samitum, Vertical loom, Patterned Silk, Silk, Viking Age

\section{INTRODUCTION}

Weaving over three decades and reading textile history written during the last 100 years made me aware that many weaving structures from the ancient times are now lost knowledge for the artisans of weaving today. My skill as a weaver is from the textile department of the Art- and-Craft school, now the University of Bergen. As a student, I saw some drawings in the book, A History of Textile Art, by the Swedish textile researcher Agnes Geijer. She showed the warp- and weft-faced compound weaves that originally were used for weaving patterned silk fabrics over one thousand years, from before 500 BEC 
China and to 300 CE on the Mediterranean coasts (Sheng 2107, p. 106, 113). I have used them in different ways, mostly for my production of religious vestments commissioned by various Norwegian churches.

Some of the silk fabrics woven in central Asia and Byzantium came to Norway, as smaller pieces of used and reused fabric, traded, given as presents from other rulers or simply stolen from monasteries in the British Isles or Europe during the Viking age (800-1050). In the recent centuries patterned silks have been found in archeological sites throughout Scandinavia. Often, due to the soil conditions, the silk fragments had decomposed to brownish pieces, where the pattern and colors are now difficult to read, making it difficult to question their influence on local pattern and craft.

Is it possible to reconstruct these fragments with the simple method I developed as a student, based on my interest in using ancient techniques for making modern textile art and craft? Can our knowledge about the development of the weaving traditions tell us more about the craft from the past? These fragments show demanding patterns and warp densities, unknown to a Scandinavian hand weaver today. They were made over a millennium ago, before the invention of the Jacquard machine in 1804 in France.

This article examines the reconstruction of a patterned silk from the Oseberg findings in Norway. What did they look like? What was the quality? How did the Vikings use them? I was curious about the weavers in the past: their skills, their looms and equipment for weaving. Other question arose: How can the weaving craft contribute to new information? Can craft help determine the provenance of an archaeological or historical object? Did the technique or pattern influence the local craft? Does this weaving technique have any meaning today, other than that of reconstructing historical textiles?

\section{THE OSEBERG BURIAL}

The richest Viking grave ever found was unearthed in 1904, outside Tønsberg near Oslo in Norway. Two women were buried in the Oseberg heap in 834. Besides the big ship, wagon, sledges, beds all in wood, the tomb contained a variety of food supplies and utensils for their afterlife. Found in the tomb were also tools for making textiles, different woven textiles and a small amount of patterned silk. Today the extant silks are only smaller pieces, probably broken from longer stripes used as decoration on clothing. We can hardly see any pattern on the brownish and decomposed fragments. They are now displayed at the Viking Ship Museum at Bygdøy and a stored in a special room at the Museum of Cultural History in Oslo (Vedeler 2020, p. 8).

Similar silk fragments were found toward the end of 1800 in Birka, a Viking trading place outside Stockholm.

In spite of the early excavation of these silks, they were not recognized and published before Geijers' doctoral thesis about the textiles found in Birka in 1938. In her and her colleague V. Sylvan's book Siden och Brokader (1931), they began by telling a saga. Legend has it that a Norwegian king sent men to Byzantium to buy woven silk, unavailable in the northern countries. However, they did not mention the silks from Birka and Oseberg. Probably, they did not know about these silk finds from the Viking graves when they wrote the book.

I asked the Historical Museum in Oslo to study the silks from Oseberg in 1980, but in vain. Today I know a new historical study on the fragment started then and it led to the publishing of all the textiles from the Oseberg burial in 834 (Christensen, 2006). The volume on textiles appeared nearly 80 years after the other four volumes about the Oseberg findings. They were published with money directly from the Norwegian Government. 

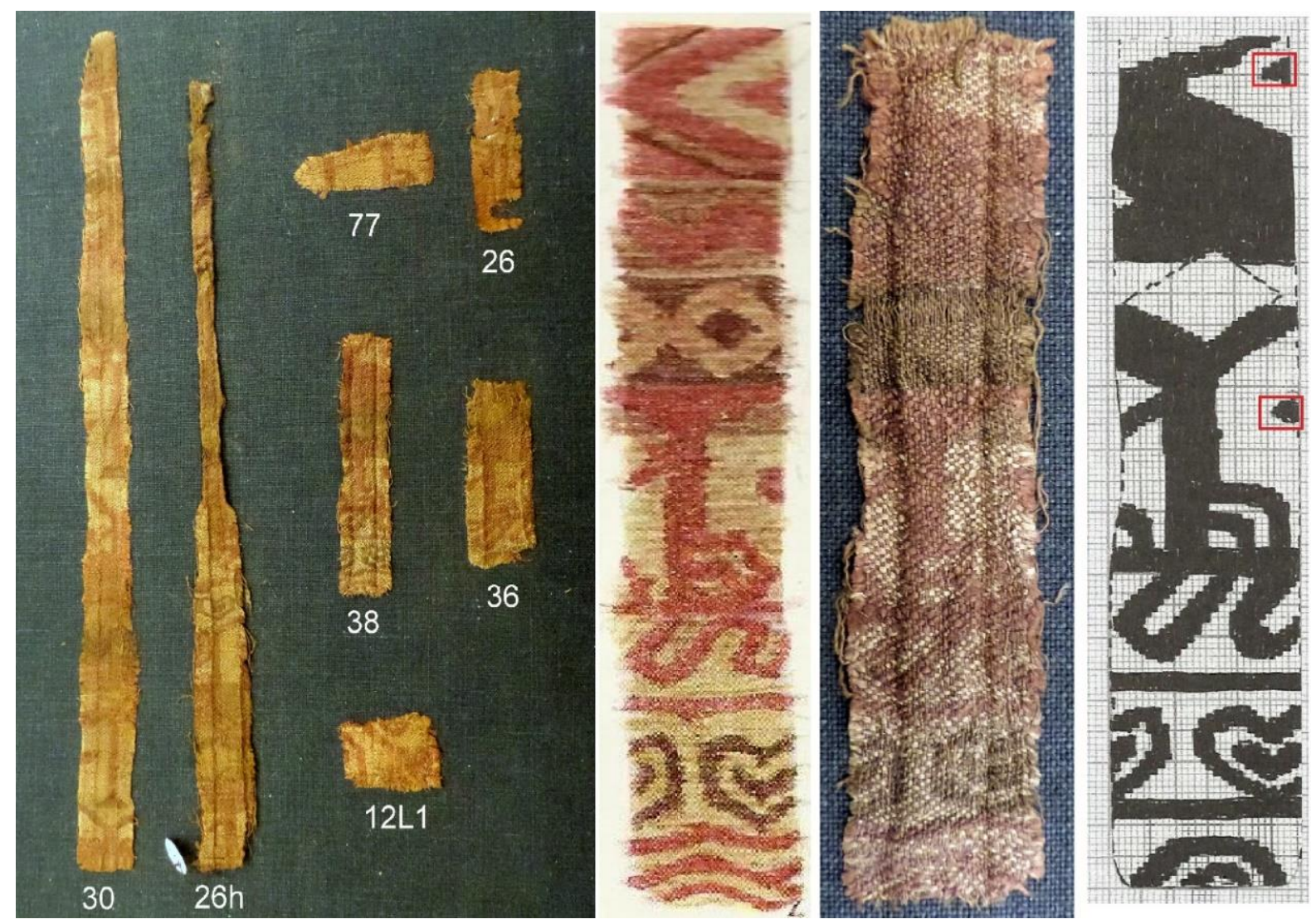

FIGUR 1-2. Fragment from fabric 3 in the Oseberg collection (figure 1). Fragment 38 from fabric 3, drawn by Krafft, photo and drawn on graph paper, the red square indicating one or two objects between the birds (figure 2).

\section{Earlier publications about the Oseberg silks}

In 1955 Sophie Krafft the artist drawing the findings from the Oseberg burial published a book with the patterns she found on the textiles as she was helping to conserve them at the Oldsakssamlingen. The textile researcher Margrethe Nockert studied the silk textiles and gave an overview over early silk fabrics in general and the ones from Oseberg specific in the official publication Osebergfunnet Tekstilene IV. She gave descriptions of the silk fabrics and in the end of her article, there is a catalog of all the fragments (Nockert 2006). Archeologist and Professor Marianne Vedeler from the Museum of Cultural History in Oslo published Silks for the Vikings in 2014, with the main focus on the Oseberg collection. Here she presented the silks found in Scandinavia from 800 to 1000, analyzed the silks, and discussed plants used for the dyestuff. My article Med silke til Valhall in Viking, Norwegian Archeologists' Yearbook 2017, focuses on the reconstruction of a silk fabric from the Oseberg collection and the technical aspect in the craft.

\section{The fragments from the Oseberg burial}

Vedeler at the Museum of Cultural History introduced me to the Oseberg collection in 2013. The collection contains 110 silk fragments from 15 different fabrics, estimated to be about eight meters of trimmings. It is not a big collection but interesting as the fabrics are woven in probably at least three different places or workshops, if woven at the same time. Fabric no. 3 , in the collection, was a promising object for my research (figure 1). There are at least 7 fragments from this fabric, cut in stripes about 1,5 - $2 \mathrm{~cm}$ wide, and from $2-27 \mathrm{~cm}$ high. There are 36-40 warp-ends per $\mathrm{cm}$ and 60-80 wefts or 30-40 passé per $\mathrm{cm}$. 
The stripes were used as decoration and sewn on the women's clothing. Bit by bit over the years all the silk is loosened from the attached cloth. Some old photos and some silk pieces formed as small leaves indicates that the silk was not just used as edging, but also as ornaments (Nockert, 2006, p. 277). Krafft also mentioned the decoration or ornaments in her book, but she did not make any notes or drawings of it (Krafft, 1955).

\section{SAMITUM, THE WEAVE-STRUCTURE IN THE SILKS}

Weft faced compound twill, samite or samitum, are some of the names used in modern literature on this weave structure. It is also known as "Byzantine twill" and "kypert-polymita" amongst others. The way the warp and weft are working together is simple, what makes the weave complex is the pattern and the apparatus or equipment that makes the pattern in the fabric. This equipment has been different and changing over the years, depending on the looms itself and other inventions, some possible tools are discussed later.

The weave-unit in samitum is a minimum of six warp threads and six weft-picks, as implied in the Greek word, hexa mitum, meaning six threads. Every other warp thread is binding the weft to the fabric. The remaining warp threads are the inner-warp, used for patterning purposes. Depending on how each inner-warp is either raised or a lowered, it will decide if the weft makes the figures or the background. At least two wefts, in two colors, work in pair in a weft-passé. On figure 4, the white binding-warp makes the twill shed for the two wefts, and as the green weft goes over one or several blue inner-warp threads the yellow weft must go under the same threads in the passè. See also the draft on figure 4.
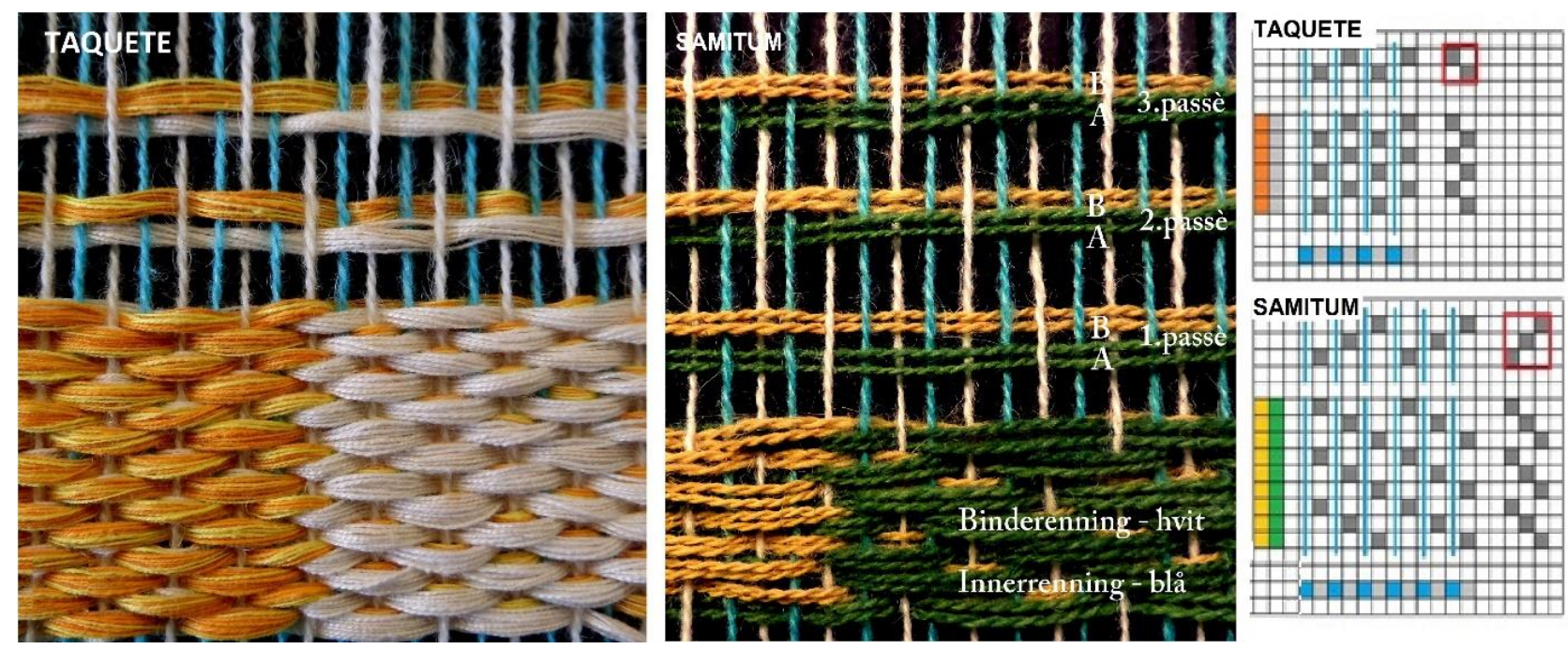

FIGURE 3-4. Structure for taquete with tabby- as the ground binding, discussed later (figure 3) and samitum with threeshafted twill as ground bindings (figure 4). The is draft showing both weave-units.

The inner-warp will be covered by wefts on the surface and on the reverse side, it will be invisible when the fabric is woven. When investigators analyze fabrics, it is easy to forget to note this inner-warp.

Knowing that the invisible inner-warp makes the pattern and knowing about the small marks the two wefts working in pairs make when they change places from being pattern to background makes it possible to note a pattern, even if the colors are gone (as in some Oseberg fragments).

By studying digitalized magnified photos and using a microscope, I found lines and figure on each of six fragments from Fabric no. 3.

Figure 5 shows the figures and lines on six fragments drawn in the same way on graph paper. Because of the variation in the weft density, I had to count and measure. The six fragments cannot be 
put together like a puzzle. But being from the same fabric, they all contain a part of the pattern unit, repeated in the fabric. An error, a double warp thread in the binding-warp, appeared in the three fragments 26h, 36 and 77 (figure 10 and 11). Once the figures on them were drawn, it was clear that the error was repeated in the same place in the bird motif in the three fragments. These three fragments had to be in the same place in the warp when the fabric was woven, in repeat units over or under each other (see the red line on figure 6). Their different size and form gave direction for the next three fragments where to fill in. The fragments also revealed a mirrored repeat.

The pattern shows two birds standing, beak to beak, on a podium with waves under and over the birds an arch filled with heart-shaped motifs. Where the birds' tails meet there is a small tree. Still, these fragments could not give all the information about the entire repeated unit. Missing is some information about the bird's beak and one or two objects between the birds, where they are standing beak to beak. Two spots on fragment number 38; seen on Kraffts drawing, on a photo of the fragment and marked in red squares on the graph paper on figure 2 shows that there are one or two objects here. The weak color painted on figure 7 indicates some imaginable figures between the two birds.

It is possible to see a pale red color in the fragments but the rest is variation of brown colors. Closer studies show that the colors in the figures had changed (in broad yellow and white stripes), and the colors in the background also changed (in narrow green/blue or black and broad red stripes) see figure 7 and 8.

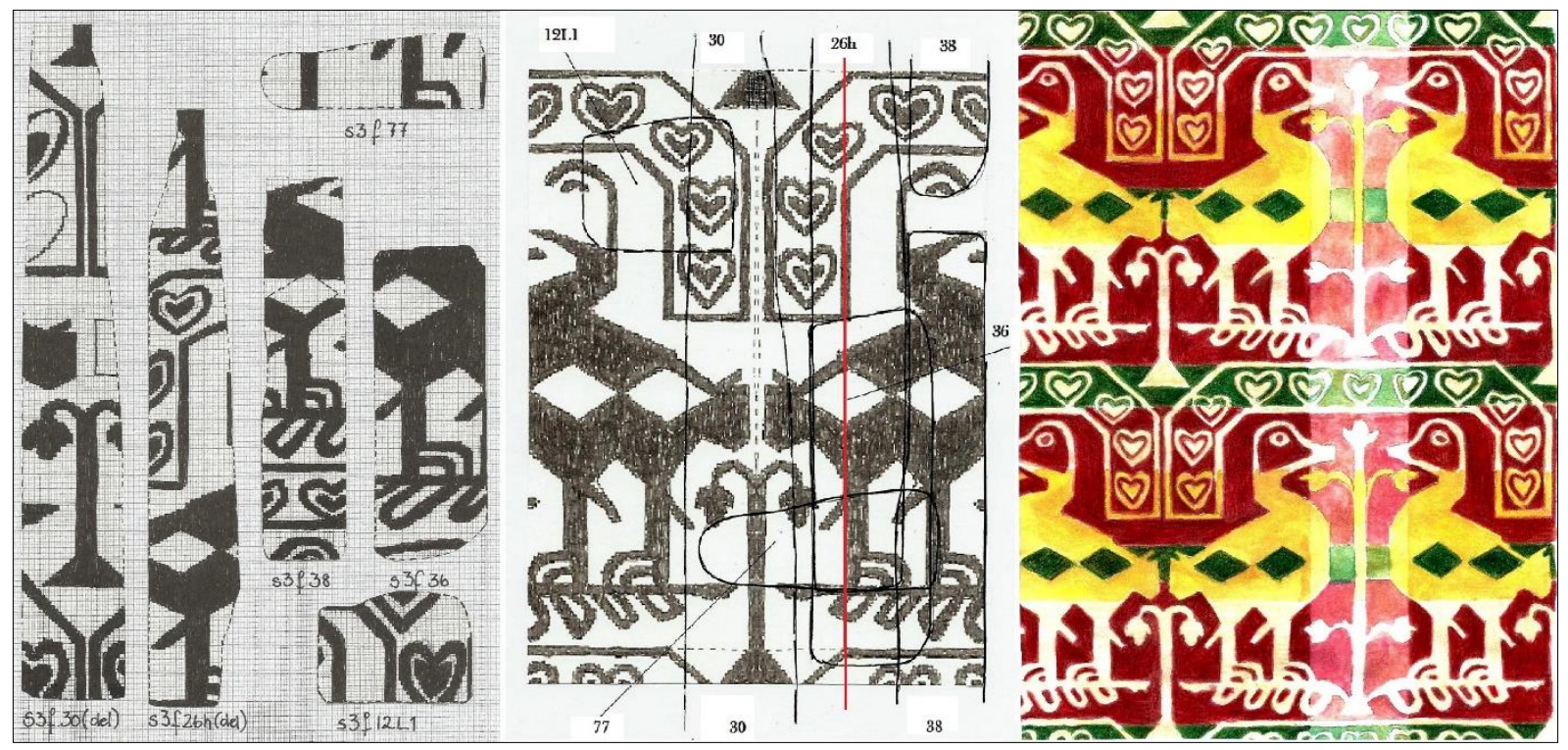

FIGURE 5-7. The six fragments drawn on graph paper (figure 5). Fragments put together with the help of a weaving mistake, noted by the red line (figure 6). A drawing of the fabric, the weak part suggests a filling in motif where no information is found (figure7).

The use of colors in the fabric seems to follow a traditional way of changing colors in certain places in the motif, compared with for example, "The Sogdian prince's jacket" at the Cleveland Museum (Eriksen, 2017, p. 53).

Regarding the dyestuff and silk material, I had to make some decisions before weaving the reconstruction. The silk available could give me the same densities as those in the original fabric, but it was spun unlike the original unspun, reeled silk. I had no information about the dyestuff in the fabric, so I used my assumptions, and my chemical dying-powder. 


\section{The work in the loom}

My approach to weaving this fabric draws from my experience in weaving samitum on a modern loom and with today's materials (- see figure 8, also showing the reverse). - I handpicked the pattern with a stick in the inner-warp, see the work on Eriksen (2015). This way of weaving works for smaller amount of patterned silk-fabric, as the pieces in the Oseberg-collection, see later.
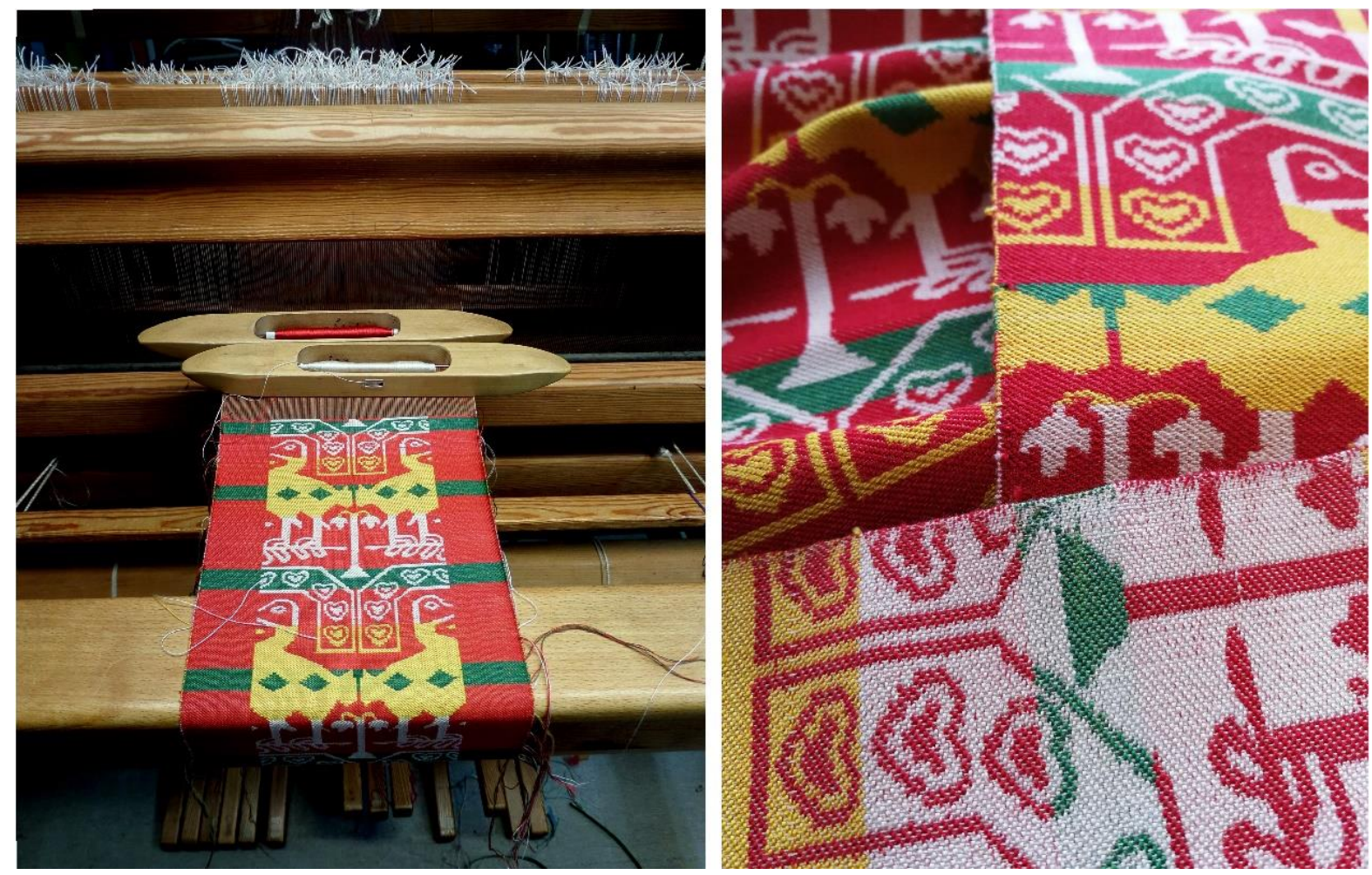

FIGURE 8. Fabric no. 3 in the loom and photo of the front and reverse of the fabric

\section{VERTICAL LOOM}

Two extant fragments may give the answer to how the loom set up was in Central Asia in 600-800. One fragment in the Victoria and Albert Museum in London (Becker, 1987, p. 83) (Kendrick 1920-22 Catalogue no. 537, plate XXV) and one in the Royal Ontario museum in Toronto (Hoskins, 2003, p. 1) (Royal Ontario fragment \#968.323.1) shows the technique taquetè (see figure 3 ) that preceded the samitum, was woven in the same fabric as tapestry weaving. This means that the two techniques, the tapestry and the taquete were woven on the same vertical loom. To weave a structure other than the tapestry on a vertical loom is unknown for a modern hand weaver. Figure 3 and 4 show taquetè and samitum, what separate them is the ground-binding, tabby in taqueté and twill in samitum, see draft on figure 4.

I made a simple test to see how it was possible to weave vertically on an open circular warp (figure 9). I put warp-threads directly on the loom, here represented by two beams. When the warp was fixed on the loom, I used half-heddles to tie the binding-warp to three ground-shafts for the twill. A thicker beam at the top raises the inner-warp over the binding-warp.

In the field, over the twill shafts I hand-pick the pattern in the inner-warp (here light red). When the figure shed $A$ is raised by a stick put on the edge and one twill shed is opened, these two sheds can merge on a stick before the weft for the figure color is shuttled. Next, the shed B for the background in the pattern can merge with the same twill shed before shuttling the weft for the background color. Seen the work on Eriksen (2014). 
Samitum has been woven on both horizontal and vertical warp in history. The way I handpicked the pattern must have been done in a very early stage of the development of taqueté and samitum. Studies of samitum fabrics from different periods can tell us more about the development of looms and equipment for repeating pattern.
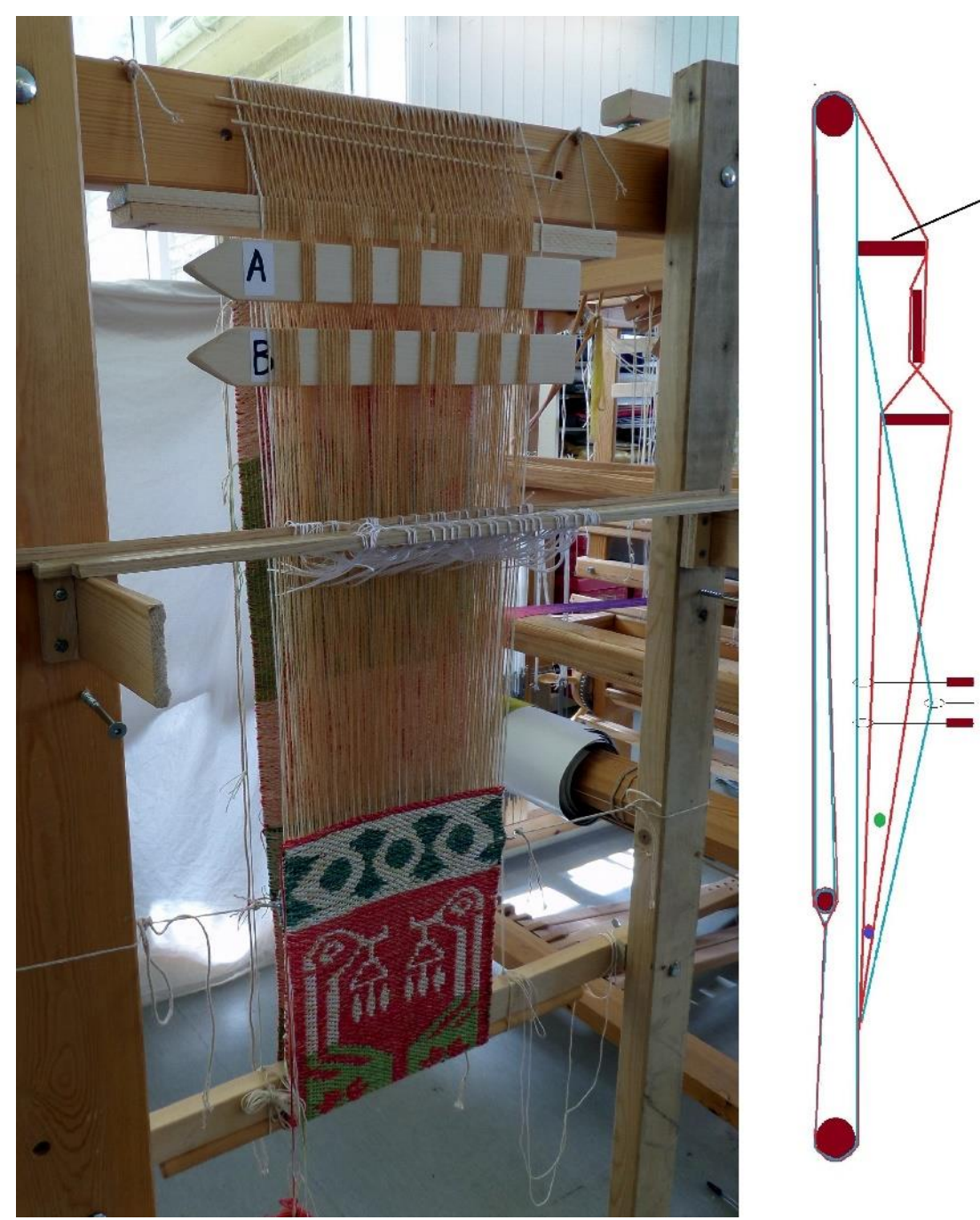

\section{A beam raises the inner-warp here the red warpends over the white/blue bindingwarp.}

The pattern are picked in this area By hand, on stick $A$, for the figures, and $B$ for the bottom in the pattern. The sticks are put on the edge for mking a shed.

FIGURE 9. A vertical warp set up on two beams. The setup is an open circular warp. To the left cross section of the set up.

\section{Pattern repeated in one direction}

The error, a weaver's mistake in the double warp thread mentioned above, can help to tell how the pattern was repeated in Fabric no. 3. Figure 10 show the mistake on the reverse side of fragments $26 \mathrm{~h}$. Figure 11 shows the mistake in three fragments from different repeat units drawn on graph paper. In the marked square, we can study the same area in two different repeat units. The pattern here is similar, but not identical, meaning the pattern is picked again for every new unit in warp direction.

Most likely, the pattern is repeated several times in the weft direction. The loom set up on figure 12 shows how pattern rods can be used to repeat a unit in the weft direction. The rods are placed in the same area as I handpicked the pattern in the previous test-loom. The inner-warps are tied with halfheddles in a numbered system of the rods. The rods are raised according to a pattern, and all the innerwarp threads tied to the raised rods in the whole width of the fabric are raised. Figure 12 shows a device for a simple pattern, but the system also works for a larger pattern unit, made possible with more rods. 

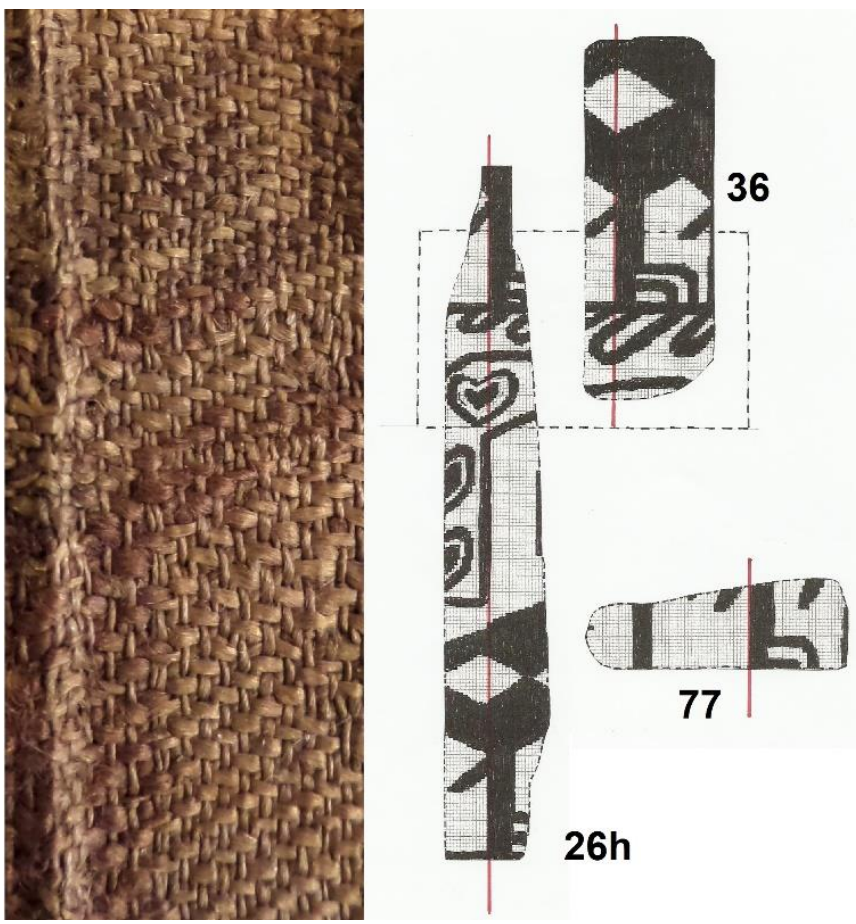

FIGURE 10-11. The mistake, a double binding-warp thread in fragment 26h, here seen on the reverse side of the fabric (figure 10). The three fragments with double warp-end marked with red lines. In the dotted square, the red line in the same place in the pattern units. The figures appear to be similar but are not identical (figure 11).

Equipment for repetition in the weft direction must have evolved long before the pattern became as complex as in Fabric 3. Figure 12 shows a small pattern with 13 rods, the unit in Fabric no. 3 is estimated to need between 120 and 130 rods. A separate system connected to the pattern rods will make it possible to store pattern for repetition also in the warp direction.
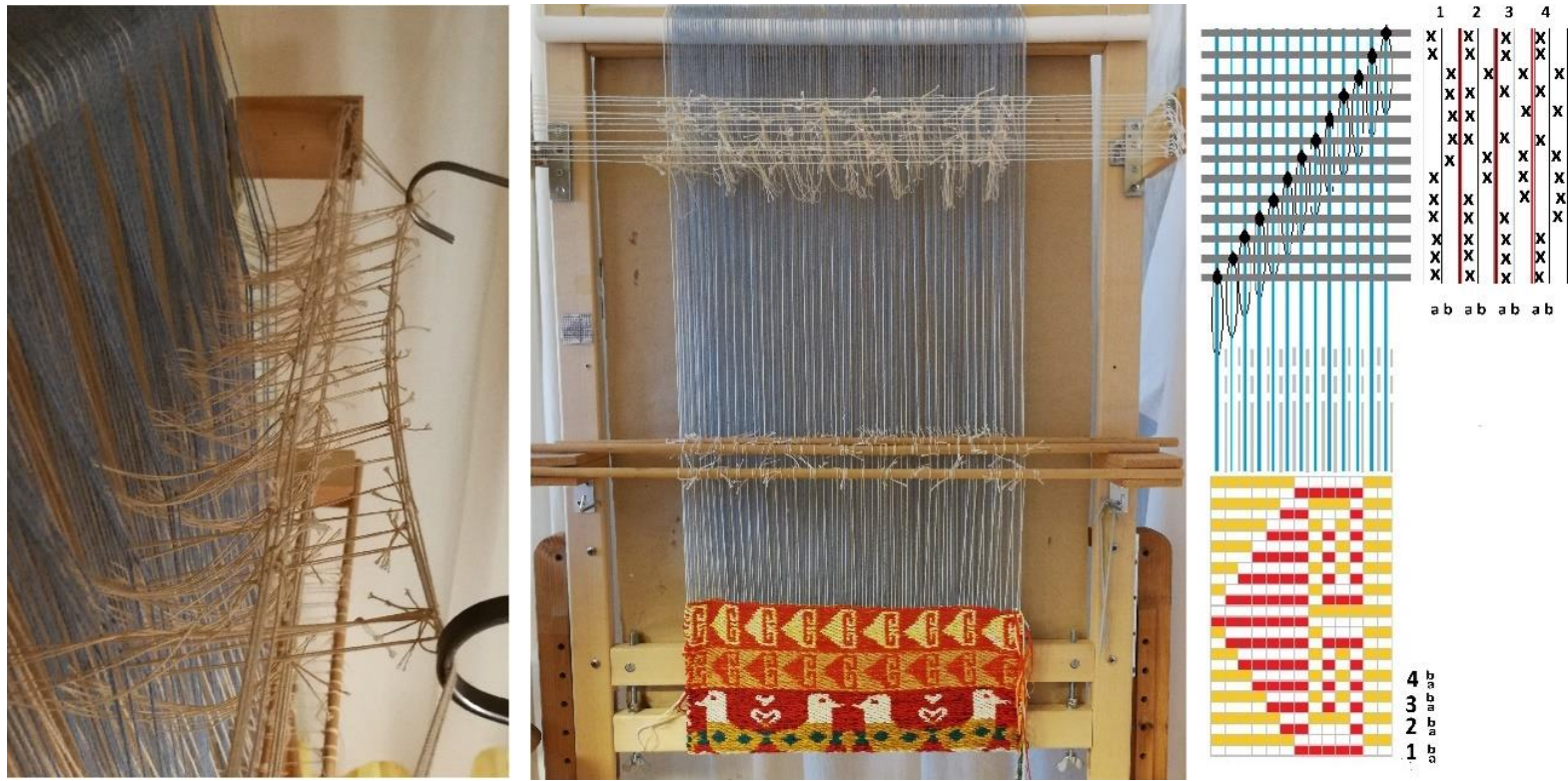

FIGURE 12. Example of a repeating pattern on a vertical loom with pattern shafts/rods. 


\section{WHAT DOES THE RECONSTRUCTION TELL US?}

When the pattern in Fabric no. 3 is clear, it and fragment 26h, 36 and 77 can tell us more about the size of the silk used on the clothing in the Oseberg grave. Fragment 26h, 36 and 77 are following each other in the warp and reveal at least five repeats. As one repeat is about $11 \mathrm{~cm}$, the length of this piece has to be minimum $55 \mathrm{~cm}$. If the piece was a square, the three remaining fragments reveal a width of nearly $10 \mathrm{~cm}$. Altogether, the six fragments tell us about four-metered stripes were used for trimming, and by extrapolation, the whole collection of 110 fragments is estimated to be about eight-meters in length.

We do not know if there were one or several decorated garments in the grave, or if the silk was sewn on homemade or imported fabrics. If the silk was sewn on fabric known as imported, the decorated garment might have been imported from for example, the British Isles. The Christians there had a close contact with Rome, and this contact gave the English access to silk fabrics, as early as 6th century and not only for use in the churches. A West Saxon churchman describes men and women wearing tunics with silk trimmed sleeves. Despite of this early supply of silk, only a small amount of silk remains in England (Crowfoot, 2001, p. 82). The Vikings and other marauders both burned religious buildings and stole valuable goods. An example of extant silks in England is the collection kept at the holy shrine of Cuthbert's in Durham. The collection of silks dates from year 600, and includes at least 10 different kinds of silks (Crowfoot, 2001, p. 83). In addition, there are lager fabrics and whole garments in this shrine (Nockert, 2006, page 298).

If the silk found in the Oseberg burial were sewn on homemade wool fabric, it is likely that the Viking woman herself cut the silk-fabric in stripes, and could have studied the patterns as models for her own craft.

\section{A Cross-plant motif}

This possibly can be seen in a woven wool tapestry, fragment 5 from Oseberg. It features a repeated cross-plant motif (Kraffts, 1955) see figure 13 left. This motif known to fill the internecine spaces between roundels in patterned silk fabrics with roundels. In the grave, there was no corresponding silk, meaning that the Vikings had more silk that was not given in the burial. The samitum silk in the middle on figure 13 is a typical example of such a motif, filling the corner where four roundels meet; it was woven in Central Asia about 700-900 (Geijer, 2006, pl. 18 c). It is interesting to see how steadfast this motif is, also comparing with the lily-cross motif on the tapestry woven coverlet for bench pillows, so called rölakan, from Sweden about 1700 - 1900 (Hansen, 1992), to the right in figure 13.

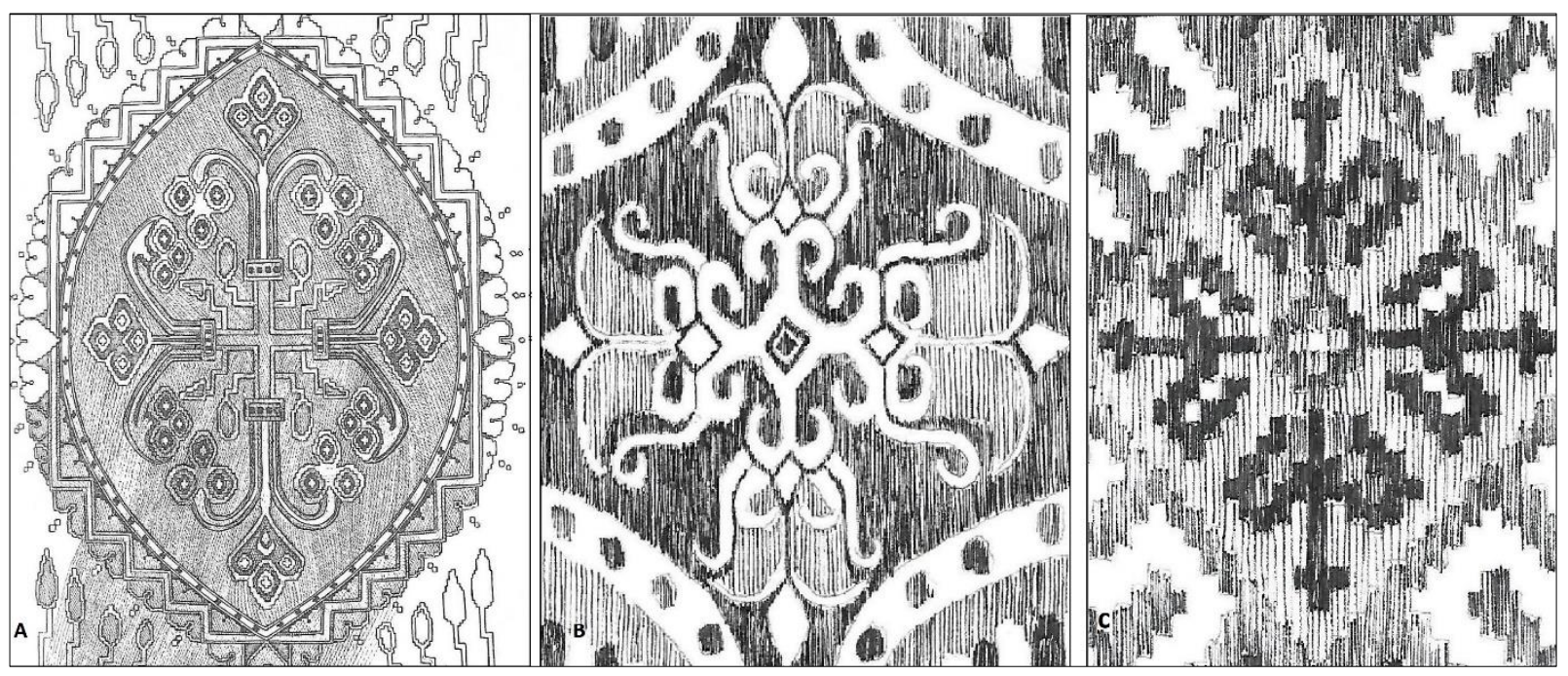

FIGURE 13. Cross plant motif. From left: in a tapestry from Oseberg burial (-834) drawn by Krafft. In the middle same motif in samtium silk (700-900). To the right a lily-cross in a rölakan from Bohuslen (1700 - 1900). 


\section{Early patterned silks influenced other woven textiles}

Motif with pearl roundels appeared in Byzantium and Sasanian Iran silk textiles about $500-1000$. Silk Fabric no. 12 in the Oseberg collection has such a roundel framing a "hunting scene" motif. Geijer sorted this out amongst the 13 fragments from this fabric, and compared it with a similar silk fabric from Mozac, now in the Historical Museum in Lyon (Geijer, 2006, PI. 20 a and b). Some rölakan in Sweden have a similar roundel motif, now turned to octagons encircling animals and plants. "Finja fragmentet" and "Jämtlands täcket" are examples of these coverlets (Hansen 1992, p. 37 and 39). There may be a direct line from the early time, but also in the mediaeval fabrics with roundel motifs were imported to Scandinavia. Half-silks/baldachin or so-called "Regensburg brocade" was imported from the early European silk production, these may also have influenced the pattern on the tapestry woven rölakan. The half-silks from Europe were woven in samitum, but with other qualities and with post-Sasanian patterns in a more heraldic style. Examples are fabrics in chasubles from Skara in Sweden and Røldal stave church in Norway (Nockert, 1984, p. 195-197)

A. Sheng in her article, Reading Textiles, states that the motif with the birds without pearl roundels (Fabric no. 3) from the Oseberg burial, clearly evolved from the earlier Sasanian model (Sheng, 2020, p. 120). This building of the repeated pattern with motifs in rows is also found in silk Fabric no. 1 in the collection, revealing the most of a bird in one fragment. Vedeler compares it with an equivalent fabric in the Vatican Museum (Vedeler, 2014, p. 13).

Around a dozen carpets patterned with birds and other figures in rows similar to that in Fabric no. 3 are found in churches all over Scandinavia. But they were woven with linen warp and wool weft. The technique used is a double weave, referring to as system D3 in Geijer (2006, p. 76). In Norway three items are found: in Sognefjord the "Heiberg-carpet", a smaller fragment in the Urnes stave church, and the third from the demolished Baldishol church in Hedemark, named the "Baldishol- carpet". These carpets were probably produced in Germany toward the end of the 1500 (Engelstad, 1952, p. 93-95). Two tapestries in Kunstindustrimuseet in Oslo, "The Knight Guiamar" and "Herod's banquet" from 1600 (Sjøvold, 1976, p. 6 and p. 46) have small areas with rows of a paired facing "lions" repeated as in a patterned fabric, perhaps indicating a curtain in the room. In "Herod's banquet" dated by the weaver to 1613 , we also find the main figures in rows framed under arches.

\section{The tree of life motif}

The Baldishol tapestry from 1200-1300 (Sjøvold, 1976, p. 48) frames; a man with a flower in his hand for April, and a rider on his horse for May, in arches as the birds in Fabric no. 3. Comparing the small tree with the birds beside the man under the arch for April with the same type of motif on fragment 15 A1 from the Oseberg findings, there is clearly a connection in this "the tree of life" motifs (see figure 14 both to the left). Fragment $15 \mathrm{~A} 1$ is a small woven fragment in plant fiber with tabby as the binding structure and the pattern is brocaded in wool on the front (Krafft, 1955 p. 36 and Hougen, 2006 p. 45).

Also, in figure 14 a "Regensburg brocade", a half-silk samitum discovered in Flåm Church in 1969 are figured with threes and birds, a "three of life" motif. This fabric is probably woven in Venice 1300 (Bugge, 1970 p. 78). A rölakan from Skytts härad in Sweden shows a very different version of "the three of life" motif (Hansen, 1992). Is the little tree and the birds on silk Fabric no. 3 also a "tree of life" motif? If so, the five versions of this motif show in spite of time and provenance how important this expression of new beginnings/life was everywhere, as they did not just copy but made their own versions. 

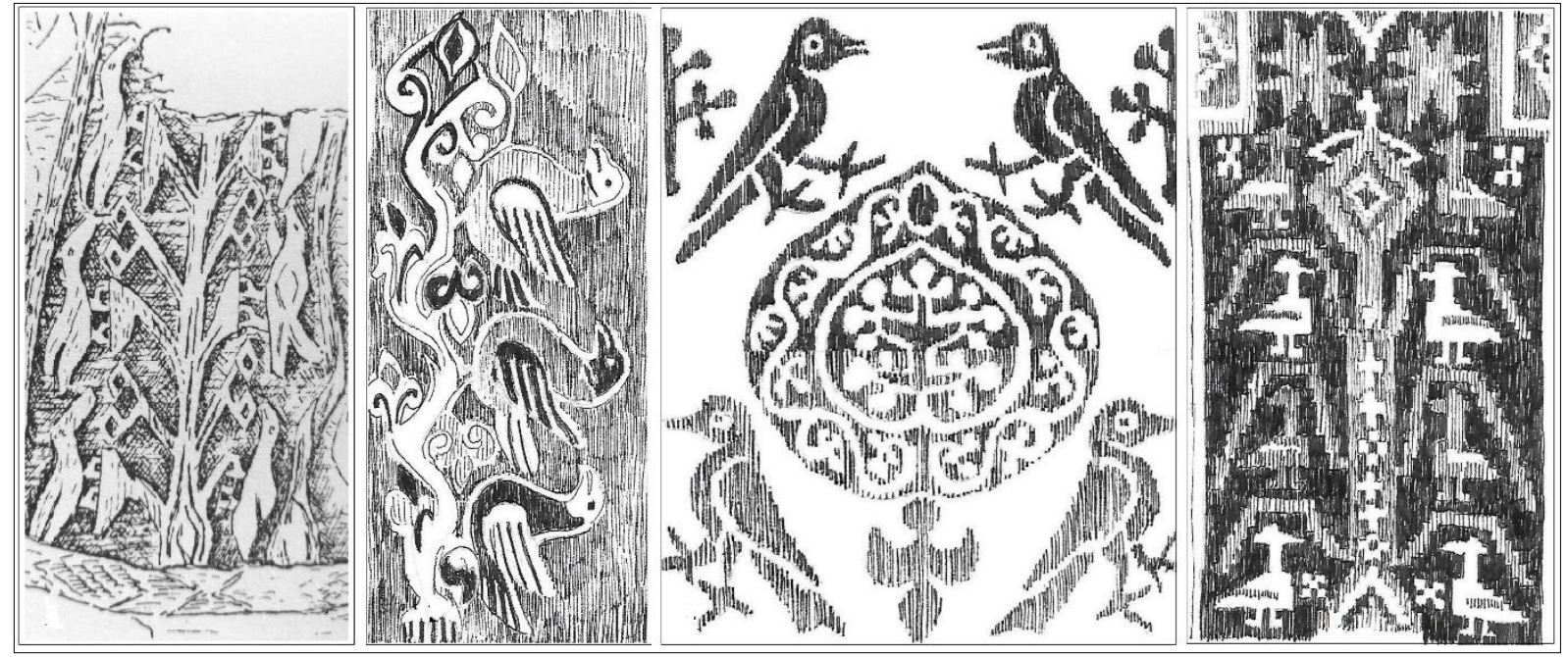

FIGUR 14. Tree of life motif. From left to right: From Oseberg (834), drawn by Krafft. Baldishol tapestry (1200-1250). Half-silk in samitum from Flåm Church, produced Venice (1300). Rölakan from Sweden (1700-1900).

\section{Has the samitum influenced the local weaving craft?}

The technique of samitum has never been worked in Norway. Different tools can be used to produce the same weave structure and it is possible to compare samitum with the technique in tablet woven band for example the one from the Evebø from 400 (Geijer, 2006, afterword), now at the University Museum of Bergen. The idea of two threads with different colors changing place to make pattern, one under and one over in a woven structure is very old. In taqueté and samitum, two wefts are working together, in the tablet woven band it is the warp-threads that is changing from being pattern to background. As in China where two or several silk threads was changing places in the weave structure in patterned Jin- silk, the color at the top, made the pattern. The most important period for production of Jin-silk was under the Han-Dynasty (205BCE - 220 AD). Often similar ideas develop separately, but there may be a basic idea for them from earlier times.

Samitum as technique disappeared during the medieval, where it in 1100-1200 became one colored fabric for embroidery (Geijer, 2006 p. 75). The structure was simplified, and become pseudodamask/proto-lamps with less use of color (Becker, 1987 p. 118) and (Schorta, 2001 p. 37). The large number of pattern shafts or harness, developed for samitum in many colors, could be exploited for virtuoso pattern in lampas-weaves. In lampas-weave the inner-warp threads that makes the pattern is not hidden, it is also makes different structures in the ground-weave. It is also possible to find remains of the technique taquetè in the Finnish/Estonian technique kuvikas, but that is another story.

Today weft-faced- and warp-faced compound weaves represent important knowledge for us to understand the development from handpicking using sticks to make figures and pattern in a fabric to digital handlooms. Parallel to the new digital looms developed for hand weavers, the interest for historical techniques is growing, but contemporary weavers are using modern fiber material and patterns.

\section{CONCLUSION}

To conclude, the work with the reconstruction was demanding, as one needed both to see the real fragments under a microscope and enlarged digitalized photos. Handwoven material with handspun and dyed yarn leaves marks and mistakes that are helpful when studying a fabric for a reconstruction, as in Fabric no. 3. When mastered to use the thin silk thread and the densities in the silk fabrics, it is possible to weave pieces of pattered fabric sized as the once that came to Scandinavia in the Viking age. As a surprise, the idea trying to weave in different ways came by itself during this work. 
Let me be clear, to weave a full-sized fabric for example $120 \times 300 \mathrm{~cm}$ is not feasible by handpicking the pattern; hence, one has to set up a loom with pattern-harness with special equipment for the constant changing of the whole pattern-shed (Becker, 1987, p. 279-283). My method works for understanding the structure, and interpret the figures on fragments and if possible, reveal a pattern unit. Also, relatively quick to weave a limited piece of the fabric, like silk Fabric no. 3 from the Oseberg Collection sixed $55 \times 10 \mathrm{~cm}$.

It is over 100 year since the silk fragments in Oseberg and other fragments in Scandinavia were unearthed, and the decomposition process is unavoidable. In my opinion, more of these historical fragmented silks can be reconstructed. At least 3 fabrics in the Oseberg collection have as many fragments as Fabric no. 3. As long as these images are hidden, we can just guess the influence they had on the people in Scandinavia and their craft before the Christianity in Scandinavia.

The images in figure 13 and 14 are examples of pattern that has been with us since the Viking age and earlier.

More work to follow. It could be interesting to try and make a vertical loom with pattern rods like they probably had in central-Asia. With densities like in the old silk fabrics. This will at least focus on hand weaving in general, and perhaps make a meeting-point for people in all professions that are interested in historic textiles.

\section{ACKNOWLEDGEMENT}

Thanks to Angela Sheng for helping me with the translation and grammar, and for sharing interest on early woven patterned silk textiles. 


\section{REFERENCES}

Becker, J. (1987). Pattern and loom. Rhodos International Publishers. http://donwagner.dk/Pattern-andLoom.pdf

Bugge, A. (1970). Tekstilfunn i Flåm kirke. In Fortidsminneforeningens årbok 1970 (pp. 75-84). Foreningen til norske Fortidsminnesmerkes Bevaring.

Crowfoot, E., Pritchard, F. \& Stainiland, K. (2001). Textiles and Clothing 1150-1450. (2. Edition). Boydell press.

Engelstad, H. (1952). Refil, Bunad og tjeld. (Fortidskunst i Norges bygder 11). Gyldendals forlag. https://www.nb.no/items/7af416966153d9213bd51ef2d5779576?page=57\&searchText=Refil,\%20buna d\%20og\%20tjeld

Eriksen, Å. (2017). Med silke til Valhall. In Viking, Norsk Arkeologisk årbok 2017. Norwegian Archaeological Society 2017, (pp. 39-85). https://doi.org/10.5617/viking.5471

Eriksen. Å. (2014) Samitum [Video]. YouTube. https://www.youtube.com/watch?v=YeFN_ScbLFU

Eriksen. A. (2015) Silkfabric from the Oseberg burial. [Video]. YouTube. https://www.youtube.com/watch?v=SkO9sh6bHzs

Geijer, A. (2006). Ur textilkonstens historia. (4. Edition). Gidlunds Förlag.

Hansen, V. (1992). Kuber och Blixtar. Institutet för Kulturforskning.

Hoskins, N. A. (2003). Technology and Tapestry in the Coptic Period. Medieval Textiles. (35), 1-10. https://www2.cs.arizona.edu/patterns/weaving/webdocs/mnm_mt35.pdf

Hougen, B. (2006). Billedvev, In A.E. Christensen \& M. Nockert (Eds.), Osebergfunnet (bind IV, Tekstilene). Kulturhistorisk Museum, Universitetet i Oslo.

Krafft, S. (1955). Fra Osebergfunnets tekstiler. Fragmenter av billedvev og silketekstiler med rekonstruerte mønstre. Dreyers forlag.

https://www.nb.no/items/54b0a7cd94a514e425cf61ec0c9dd02d?page=0\&searchText=Sofie\%20Krafft

Nockert, M. (1984). Mässhakan från Röldal, In T. Gjerdi, A. Kjellberg \& G. AA. Rosander. By og bygd, Festskrift til Marta Hoffmann. Norsk folkemuseums årbok 1983-84 (Bind xxx)(pp. 195-200). Norsk folkemuseum. https://www.nb.no/items/a27bef4e3321b3463cbbce251bc42cbd?page=0\&searchText=Festskrift\%20til \%20marta\%20Hoffmann

Nockert, M. (2006). Siden. In A. E. Christensen \& M. Nockert. Osebergfunnet (bind IV, Tekstilene). (pp. 277-337). Kulturhistorisk Museum, Universitetet i Oslo.

Sheng, A. (2020). Reading Textiles, Transmission and Technology of Silk Road Textiles in the First Millennium. In Harris, J (Ed). A Companion to Textiles. (pp. 109-126). John Wiley \& son. https://doi.org/10.1002/9781118768730.ch6

Sheng, A. (2017). Chinese silks that circulated among people north and west: implications for technological excange in early times. In B. Hildebrandt with C. Gillis. (Eds.). Silk. (pp. 104-123). Oxbow Books. https://doi.org/10.2307/j.ctvh1dsv4.12

Sjøvold, Aa. B. (1983). Norsk Billedvev (3. Edition). Huitfeldt Forlag. https://www.nb.no/items/43273ce12c05440e51991ddd031a0b45?page=0\&searchText=Aase\%20Bay\% 20sj\%C3\%B8vold

Sylvan, V. \& Geijer, A. (1931). Siden och Brokader. Bokförlaget Natur och Kultur.

Vedeler, M. (2019). Oseberg de gåtefulle billedvevene. Scandinavian Academic Press.

Vedeler, M. (2014). Silks for the Vikings. (Ancient textiles series, vol. 15). Oxbow books. https://doi.org/10.2307/j.ctvh1dtt3

Wang, M. (1983). Ruteåkler. Universitetet I Bergen. 